\title{
Combining crop diversification practices can benefit cereal production in temperate climates
}

\author{
Carolina Rodriguez $^{1}$ (D) $\cdot$ Linda-Maria Dimitrova Mårtensson ${ }^{1} \cdot$ Erik Steen Jensen ${ }^{1} \cdot$ Georg Carlsson $^{1}$
}

Accepted: 19 May 2021 / Published online: 30 June 2021

(C) The Author(s) 2021

\begin{abstract}
Diversifying cropping systems by increasing the number of cash and cover crops in crop rotation plays an important role in improving resource use efficiency and in promoting synergy between ecosystem processes. The objective of this study was to understand how the combination of crop diversification practices influences the performance of arable crop sequences in terms of crop grain yield, crop and weed biomass, and nitrogen acquisition in a temperate climate. Two field experiments were carried out. The first was a 3-year crop sequence with cereal or grain legume as the first crops, with and without undersown forage legumes and forage legume-grass crops, followed by a cereal crop. The second experiment was a 2-year crop sequence with cereal or legume as the first crops, a legume cover crop, and a subsequent cereal crop. For the first time, crop diversification practices were combined to identify plant-plant interactions in spatial and temporal scales. The results partly confirm the positive effect of diversifying cereal-based cropping systems by including grain legumes and cover crops in the crop sequence. Legume cover crops had a positive effect on subsequent cereal grain yield in one of the experiments. Using faba beans as the first crop in the crop sequence had both a positive and no effect on crop biomass and $\mathrm{N}$ acquisition of the subsequent cereal. In cover crops composed of a forage legume-grass mixture, the grass biomass and $\mathrm{N}$ acquisition were consistently increased after the grain legume, compared to the cereal-preceding crop. However, differences in the proportion of legume to grass in mixture did not influence crop yield or $\mathrm{N}$ acquisition in the subsequent cereal. In conclusion, these results support that increased crop diversity across spatial and temporal scales can contribute to resource-efficient production and enhance the delivery of services, contributing to more sustainable cropping systems.
\end{abstract}

Keywords Crop sequence $\cdot$ Grain legumes $\cdot$ Cover crops $\cdot$ Intercropping $\cdot$ Forage legumes $\cdot$ Plant mixtures

\section{Introduction}

In European agriculture, cropping systems have been simplified to facilitate crop management of large-scale fields (Landis 2017). The types of crop rotations have been reduced to include only a few resource-demanding crop species, which may be profitable while making crop production vulnerable to pests and diseases (Altieri et al. 2015). There is considerable interest in spatially and temporally diversifying cropping systems to enable the delivery of a wider range of products and

Carolina Rodriguez

carolina.rodriguez@slu.se

1 Department of Biosystems and Technology, Swedish University of Agricultural Sciences, P.O. Box 190, SE-234 22 Lomma,

Uppsala, Sweden raw materials and to contribute to multiple functions and ecosystem services, thus facilitating a higher degree of sustainability in agroecosystems (Liebman and Dyck 1993; Wezel et al. 2014). Combining different plant characteristics and functional traits (e.g., soil cover, root growth, nutrient retention, symbiotic nitrogen fixation, and nectar-rich flowers) may improve soil quality and nutrient availability to crops; reduce soil nutrient losses (Tonitto et al. 2006); provide habitats for pollinators (Wezel et al. 2014); minimize the risk associated with weeds, pests, and diseases (Angus et al. 2015); and reduce the requirement for synthetic fertilizers and pesticides (Davis et al. 2012).

Crop diversification can be defined as the increase in crop diversity through the implementation of practices such as intercropping, cover crops, diversified crop rotations, and integration of perennial crops. Intercropping, i.e., the cultivation of two or more species in the same field simultaneously, for at least part of their growth cycle, has been shown to improve 
yields and stability with reduced inputs when one of the components is a legume (Bedoussac and Justes 2010; Raseduzzaman and Jensen 2017), especially in low N-input and organic farming systems. The increase in yield may occur by the complementarity effect in the intercropping, allowing for a more efficient use of resources (Hauggaard-Nielsen et al. 2012). For instance, in cereal-legume intercropping, cereals tend to be more competitive for soil mineral nitrogen at the beginning of their growth cycle than legumes, and therefore legumes are forced to rely on atmospheric nitrogen fixation. In the case of implementing cover crops in the crop rotation, they may offer weed suppression through increased competition, reduce $\mathrm{N}$ leaching, and promote soil organic carbon sequestration (Abdalla et al. 2019; Poeplau and Don 2015; Valkama et al. 2015). Furthermore, diversifying crop rotations with legumes will both complement and facilitate the capture and cycling of nutrients by the legume input of biologically fixed nitrogen and the carryover effect of nutrients to the following crop (Peoples et al. 2009). However, the variation in the use of resources due to the inclusion of different species or groups of species in the crop sequence generates challenges in following the mechanisms involved in resource acquisition and thus requires a better understanding of the interactions between species and the consequences of niche differentiation in the cropping system.

Several studies have shown the capacity to diversify crop rotation to influence yield responses on the subsequent crop. For example, the combination of undersown forage legumes in winter wheat and lower fertilization rates may increase the soil $\mathrm{N}$ availability and thus benefit the subsequent spring crop (Bergkvist et al. 2011). Similarly, the combination of grain legumes and cover crops in a rotation may reduce the $\mathrm{N}$ fertilization rates without affecting the yields of the subsequent cereal (Plaza-Bonilla et al. 2017). Since the dynamics of resource acquisition is context specific, a better understanding is needed on the combination of different crop diversification practices in both time and space (Fig. 1). Nevertheless, most previous studies of crop diversification have focused on single practices, e.g., the integration of cover crops or diversification of the crop rotation, and results from studies of combined diversification practices are very scarce in the scientific literature. Knowledge about synergies and trade-offs when combining several crop diversification practices is key in providing decision support for the practical implementation of crop diversification.

The aim of this study was to investigate how the combination of several crop diversification practices affects plant-plant interactions and crop performance in cereal-based crop rotation sequences in a temperate climate. More specifically, we introduce grain and forage legumes as a sole crop or in mixture (intercropping) and undersown cover and forage crops to determine how increasing crop diversity in the cropping systems influences the use of $\mathrm{N}$ resources, weed suppression, and crop yields. In two field experiments with cereal-based crop sequences, we determined the effects of the following three crop diversification practices individually and in combination: diversified rotation, cover crops, and intercropping. We hypothesized that:

i) The yield and total $\mathrm{N}$ accumulation of the subsequent cereal crops will be influenced by the crops earlier in the crop sequence through niche differentiation between the nutrient acquisition strategies of legume and non-legume crops. This result will be more pronounced when intercropping legumes and non-legumes in forage crops since higher competition for soil $\mathrm{N}$ resources will promote biological $\mathrm{N}_{2}$ fixation in the forage legume component.

ii) The yield of the first crop will not be influenced when a forage or cover crop is undersown, due to the complementarity created by the niche differentiation in the nutrient acquisition strategies of legume and non-legume
Fig. 1 Combination of crop diversification practices: a lucerne-cocksfoot undersown in faba bean field, and $\mathbf{b}$ lucerne undersown in faba bean field.
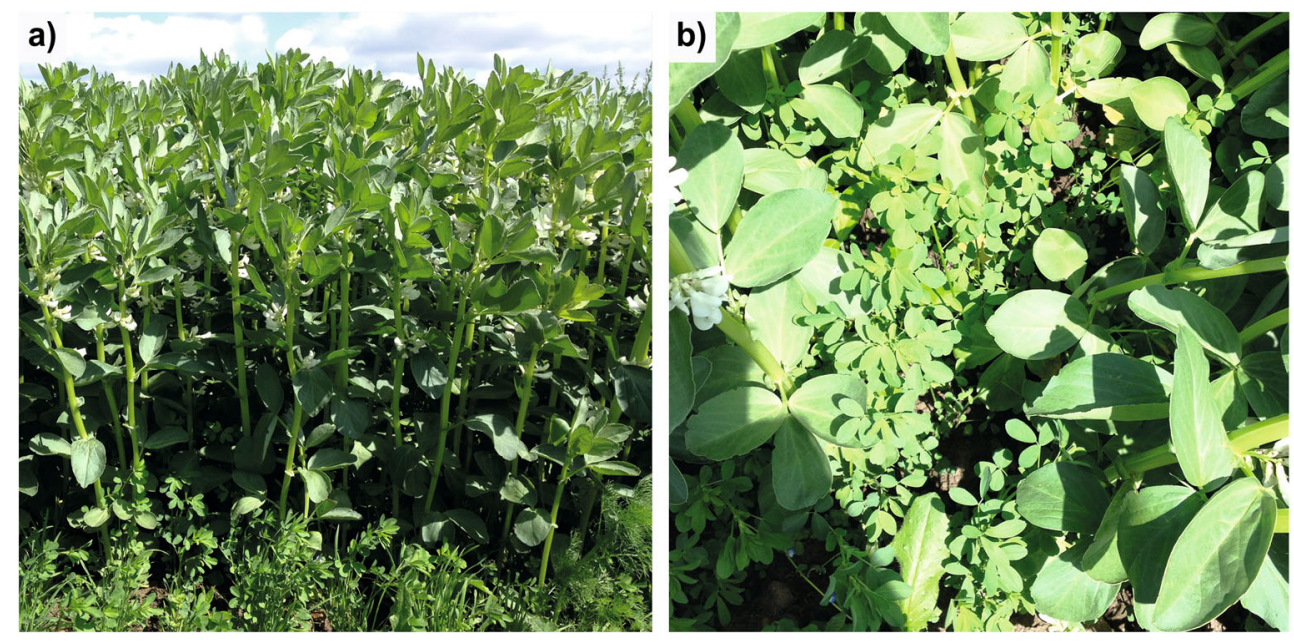
crops as well as by temporal differences in resource needs between the main and undersown crops.

iii) Adding a forage crop or cover crop into the crop sequence will provide increased weed suppression since the competition for resources will extend to a longer period as compared to sequences without cover/forage crops.

\section{Materials and methods}

\subsection{Study site}

Two field experiments were established at the SITES Lönnstorp Research Station (Fig. 2), SLU Alnarp (55 38' $\mathrm{N}, 13^{\circ} 3^{\prime} \mathrm{E}$ ). The soil is a loam (Eutric Cambisol according to FAO classification) with $10-20 \%$ clay $(<0.002-\mathrm{mm}$ particle size), 30-40\% silt (0.002-0.06-mm particle size), 40-50\% sand (0.06-2-mm particle size), 2-4\% organic matter (1$2.5 \%$ organic carbon), and $\mathrm{pH}_{\mathrm{H} 2 \mathrm{O}}$ of $6.5-7.5$ in the top (0$20 \mathrm{~cm}$ ) soil profile. Soil phosphorous $(\mathrm{P})$ and potassium $(\mathrm{K})$ availability at the site are around $0.1 \mathrm{~g} \mathrm{~kg}^{-1}$ of ammonium lactate (AL) extractable P, $0.5 \mathrm{~g} \mathrm{~kg}^{-1}$ total $\mathrm{P}, 0.09 \mathrm{~g} \mathrm{~kg}^{-1}$ AL-extractable $\mathrm{K}$, and $1 \mathrm{~g} \mathrm{~kg}^{-1}$ total $\mathrm{K}$. The total annual precipitation and mean annual temperatures during the experimental period between 2015 and 2017 were $699 \mathrm{~mm}$ and $9^{\circ} \mathrm{C}$ in $2015,667 \mathrm{~mm}$ and $9^{\circ} \mathrm{C}$ in 2016 , and $656 \mathrm{~mm}$ and $9^{\circ} \mathrm{C}$ in 2017 (LantMet-SLU 2020). The annual potential evapotranspiration in the region is between 500 and $700 \mathrm{~mm}$ (Brandt and Grahn 1998). The field experiments were carried out on land used for conventional crop rotation with oilseed rape, winter wheat, sugar beet, and spring barley. In the growing season before establishing the experiments, winter wheat was grown on the field used in Experiment 1 and sugar beet in the field of Experiment 2 (see below).

\subsection{Experimental sequences, establishment, and management}

In Experiment 1, a 3-year crop sequence was employed from 2015 to 2017. Faba bean (F) (Vicia faba L., cv. Gloria) and oats (O) (Avena sativa L., cv. Symphony) were the first crops in the crop sequence, grown without an undersown forage crop (denoted No_CC) and with undersown forage legume or forage legume-grass mixtures (relay cropping-also functioning as cover crop during the first autumn-winter-spring). The undersown forage crops (referred to as second crop) were either lucerne (L) (Medicago sativa L., cv. Daphne) or red clover (RC) (Trifolium pratense L., cv. Titus) in pure stands or mixtures of lucerne and cocksfoot (Dactylis glomerata L., cv. Donata) $(\mathrm{L}+\mathrm{C})$, and red clover with timothy $(\mathrm{RC}+\mathrm{T})$ (Phleum pratense L., cv. Switch). The first crops were sown at 60 (faba bean) and 450 (oats) viable seeds $\mathrm{m}^{-2}$, according to regional recommendations for plant densities of spring-sown crops. Forage crops were sown into the annual first crop at their recommended sowing density for establishment as sole crops: $15 \mathrm{~kg} \mathrm{ha}^{-1}$ lucerne seeds in L, $7.5 \mathrm{~kg} \mathrm{ha}^{-1}$ lucerne seeds and $10 \mathrm{~kg} \mathrm{ha}^{-1}$ cocksfoot seeds in $\mathrm{L}+\mathrm{C}$ ( $50 \%$ of each species), $12 \mathrm{~kg} \mathrm{ha}^{-1}$ red clover seeds in $\mathrm{RC}$, and $6 \mathrm{~kg} \mathrm{ha}^{-1}$ red clover seeds and $6 \mathrm{~kg} \mathrm{ha}^{-1}$ timothy seeds in $\mathrm{RC}+\mathrm{T}(50 \%$ of each species). The field was plowed and harrowed in spring before sowing the first crops and the undersown forage crops, with a Wintersteiger-Öyjord experimental sowing machine on 22 April 2015 (sowing depth: 5-6 cm). The forage crops were sown in a second passing directly after the first crops to place

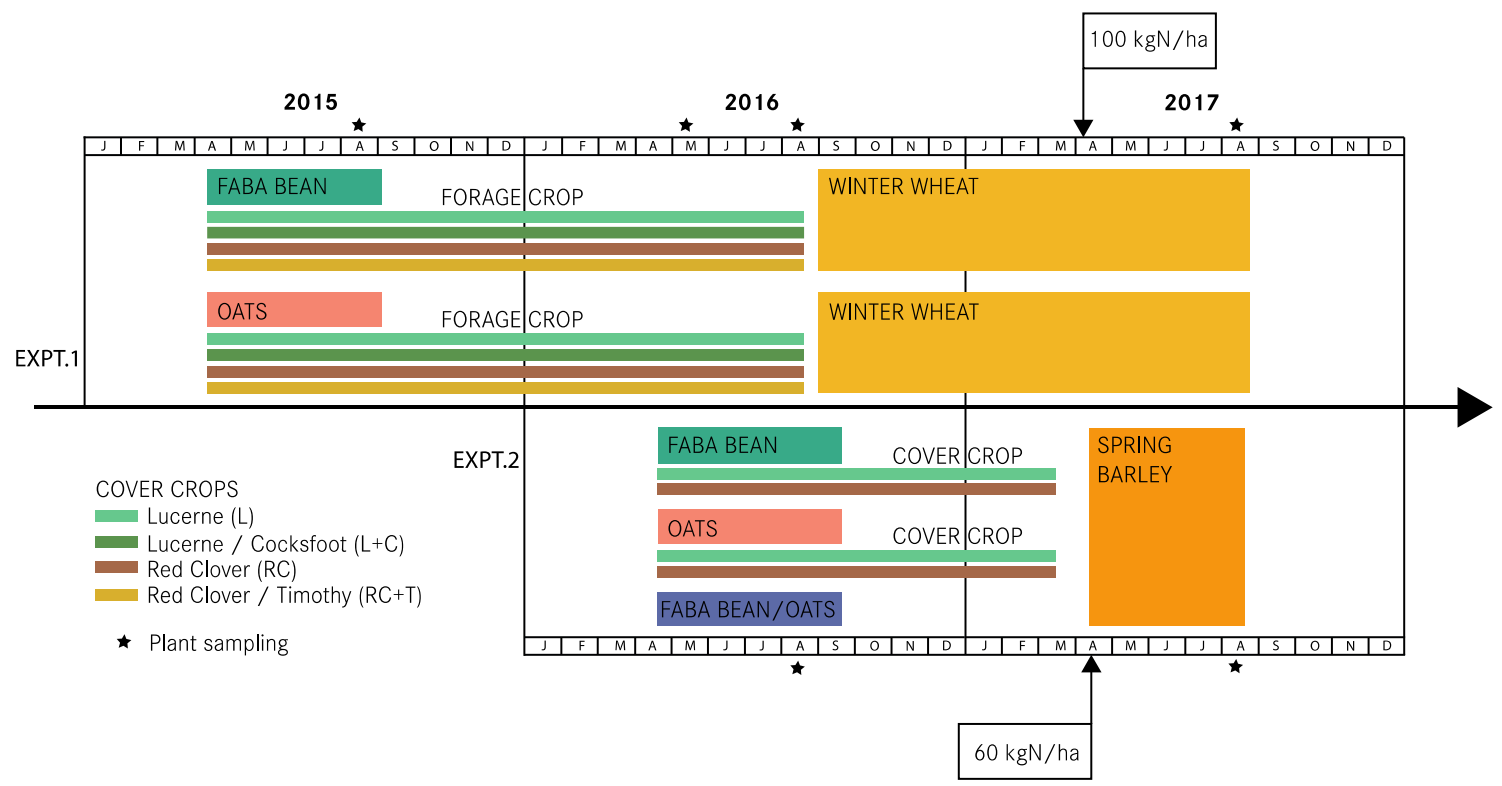

Fig. 2 Illustration of the crop sequences in the field experiments. 
the small forage legume and grass seeds less deeply in the soil than the grain legume and cereal seeds. The row spacing in all treatments in the experimental plots was $12 \mathrm{~cm}$. Lucerne seeds were inoculated with a commercial inoculant before sowing, while red clover seeds were not inoculated (rhizobia that nodulate clover are known to be present in the soil). The experimental plots were laid out in a complete randomized block design consisting of $12 \times 2-\mathrm{m}$ plots, with each crop sequence replicated four times. These field experiments were part of a larger experimental design in a 4-year project called LEGATO (Legumes for the Agriculture of Tomorrow). No fertilizers or pesticides were applied during the first year of the experiments, and there was no mechanical weed control after sowing. Faba bean and oats were harvested on 2 September 2015, with an experimental plot combine harvester, which collects the grains and distributes the straw (chopped into $5-10-\mathrm{cm}$ pieces) on the surface of the harvested plot. The biomass of the forage crops was also cut and left on the surface of the plot. The forage crops were then left to re-grow until the end of May in the following year when they were harvested using a forage harvester which cut the plants at approx. $10 \mathrm{~cm}$ above ground, collected, and removed the cut biomass from the plots. The forage crops were then allowed to re-grow until mid-August when they were harvested again with the same machine (aboveground biomass removed). No fertilizer was applied, nor was there any chemical or mechanical control of weeds or pests during the second year of the crop sequence. Two weeks after the second harvest of the cover crops, the plots were plowed to a depth of $25 \mathrm{~cm}$ (2 September 2016), and the field was harrowed twice before sowing winter wheat (Triticum aestivum L., cv. Brons; third crop in the sequence) on 19 September 2016 at a density of approx. 370 viable seeds $\mathrm{m}^{-2}$ (according to regional recommendations). The wheat was not fertilized during the autumn but received $100 \mathrm{~kg} \mathrm{~N} \mathrm{ha}^{-1}$ $\left(56 \mathrm{~kg} \mathrm{~N}\right.$ as $\mathrm{NH}_{4}^{+}, 44 \mathrm{~kg} \mathrm{~N}$ as $\mathrm{NO}_{3}{ }^{-}$), with $11 \mathrm{~kg} \mathrm{ha}^{-1}$ each of $\mathrm{P}$ and $\mathrm{K}$ on 18 April 2017. A herbicide treatment with Ariane ${ }^{\mathrm{TM}} \mathrm{S}\left(21 \mathrm{ha}^{-1}\right.$; active ingredients: MCPA $20 \%$, fluroxypyr $4 \%$, and clopyralid $2 \%$ ) was applied on 30 May 2017. The wheat was harvested on 22 August 2017 using the same experimental combine harvester as for the first crops in 2015.

Experiment 2 was established in 2016 and comprised a 2year crop sequence. Faba bean (cv. Gloria, 60 viable seeds $\mathrm{m}^{-2}$ ) and oats first crops (cv. Belinda, 425 viable seeds $\mathrm{m}^{-2}$ ) were sown as sole crops with and without undersown lucerne (cv. Daphne, $15 \mathrm{~kg}$ seeds ha $^{-1}$ ) or red clover (cv. Titus, $12 \mathrm{~kg}$ seeds $\mathrm{ha}^{-1}$ ). In this case, the undersown forage legumes only have the function as cover crops since they were not harvested and destroyed after the first winter. No forage legume-grass mixture was included as cover crop in Experiment 2, but an intercrop of faba bean and oat (50\% density of each species, seeds mixed before sowing) without undersown cover crop was included as an additional first crop treatment. The first crops and undersown cover crops were sown on 22 April 2016 after plowing and harrowing the field, as described above for Experiment 1 regarding plot size, experimental design and replication, sowing depth, and row spacing. No fertilization, pesticide application, or mechanical weed control was applied during the first year after sowing. The first crops were harvested on 22 August 2016, with the same straw management as in Experiment 1, and the cover crops were left to re-grow until 23 March 2017, when they were destroyed by herbicide (glyphosate, $1.8 \mathrm{~kg}$ active ingredient per ha) before sowing spring barley (Hordeum vulgare L., cv. Planet, approx. 375 viable seeds $\mathrm{m}^{-2}$ ) by direct drilling (no tillage) on 11 April 2017. For this establishment, a special-built experimental sowing machine was used, with discs that place seeds in untilled soil. The spring barley (second crop in the sequence) was fertilized with $60 \mathrm{~kg} \mathrm{~N} \mathrm{ha}^{-1}\left(33 \mathrm{~kg} \mathrm{~N}\right.$ as $\mathrm{NH}_{4}{ }^{+}, 27 \mathrm{~kg} \mathrm{~N}$ as $\mathrm{NO}_{3}{ }^{-}$) and $6,7 \mathrm{~kg} \mathrm{ha}^{-1}$ each of $\mathrm{P}$ and $\mathrm{K}$, on 18 April 2017, and herbicide Ariane ${ }^{\mathrm{TM}} \mathrm{S}\left(21 \mathrm{ha}^{-1}\right.$; active ingredients: MCPA $20 \%$, fluroxypyr $4 \%$, and clopyralid $2 \%$ ) and fungicide Flexity ${ }^{\circledR}\left(0.31 \mathrm{ha}^{-1}\right.$; active ingredient: metrafenone) were applied on 23 May 2017. The spring barley crop was harvested on 19 August 2017 with the same combine harvester as in Experiment 1.

\subsection{Plant sampling and analysis}

Aboveground plant biomass of the first crops and forage crops was sampled in the last week of August 2015, and the forage and crops in the last week of May and first week of August in 2016 in Expt. 1 and the first crops and cover crops in Expt. 2 were sampled in mid-August 2016. The third crop in Expt. 1 (winter wheat) and second crop in Expt. 2 (spring barley) were sampled in mid-August 2017. The samples were collected by hand, cutting $5-\mathrm{cm}$ above ground level in two $0.25 \mathrm{~m}^{2}$ subplots per experimental plot. The intercrops and mixtures were sorted into legumes, grasses, and cereals, while the weed species were pooled into one sample. Thus, total weed biomass and $\mathrm{N}$ content at crop harvest were used as an integrated measurement of weed growth and $\mathrm{N}$ accumulation during the period of crop growth, to assess if and how the crop diversification practices influenced the crops' competitive ability against weeds. The aboveground biomass of the sorted grain and forage legume, grass, cereal, and weed samples was dried at $60^{\circ} \mathrm{C}$ for $24 \mathrm{~h}$ and milled to a fine powder. Samples were packed into tin capsules and the $\mathrm{N}$ concentration analyzed using a Flash 2000 Thermo Scientific elemental analyzer (at SLU, Alnarp, Sweden). The N concentration and ${ }^{15} \mathrm{~N}$ abundance of the cover crops were measured in 2016 in Expt. 1 using an elemental analyzer (CE 1110, Thermo Electron, Milan, Italy) coupled in continuous flow mode to a Finnigan MAT Delta Plus isotope ratio mass spectrometer (Thermo Scientific, Bremen Germany) at Copenhagen University, Denmark. Grain yields of the cereals and grain legumes were 
determined by direct measurements of fresh weight yield per plot using the experimental combine harvester, and subsamples from each plot were used to determine the dry matter content and the fraction of crop grains (sorted per species for intercrops), weed seeds, and crop residues in the harvested grains.

\subsection{Calculations}

The nitrogen accumulation was calculated by multiplying the $\mathrm{N}$ concentration by the biomass dry weight. $\mathrm{N}_{2}$ fixation in the legume cover crops was determined using the ${ }^{15} \mathrm{~N}$ natural abundance method (Unkovich et al. 2008). The proportion of nitrogen derived from the atmosphere (\%Ndfa) in legumes was calculated based on their deviation from atmospheric ${ }^{15} \mathrm{~N}$ abundance $\left(\delta^{15} \mathrm{~N}_{\text {leg }}\right)$ (Eq. 1), using the mean $\delta^{15} \mathrm{~N}$ value in grass growing together with lucerne and red clover from each block as the reference, $\delta^{15} \mathrm{~N}_{r e f}$. Grass growing in mixture with the forage legumes was chosen as reference plants to avoid over-estimation of \%Ndfa, as recommended by Carlsson and Huss-Danell (2014). The correction factor associated with symbiotic $\mathrm{N}_{2}$ fixation processes $\beta$ was -0.92 for lucerne and -1.30 for red clover (Unkovich et al. 2008). The amount of nitrogen fixed (Ndfa) was calculated from the product of nitrogen accumulation in the legume cover crop (N accumulation $_{\text {leg }}$ ) and \%Ndfa (Eq. 2). Soil $\mathrm{N}$ acquisition (Ndfs) was calculated as the difference between the total crop $\mathrm{N}$ accumulation and the Ndfa for legumes and was assumed to be equal to the total $\mathrm{N}$ acquisition in grasses.

$$
\begin{aligned}
& \% N d f a=100 \times \frac{\delta 15 \mathrm{~N}_{\text {ref }}-\delta 15 \mathrm{~N}_{\text {leg }}}{\delta 15 \mathrm{~N}_{\text {ref }}-\beta} \\
& N d f a\left(\mathrm{~kg} \mathrm{ha}^{-1}\right)=N \text { accumulation }_{\text {leg }} \times \frac{\% N d f a}{100}
\end{aligned}
$$

\subsection{Statistical analysis}

Total dry matter contents of legumes, grasses, cereals, and weeds were log-transformed before analysis to fulfill the requirement for a normal distribution. A two-way analysis of variance (ANOVA), with a significance level of $p<0.05$, was conducted on linear mixed effect models to determine the effect of fixed factors (first crops and forage/cover crops) on each dependent variable, e.g., total dry matter yield, grain yield, $\mathrm{N}$ accumulation, proportion, and amount of $\mathrm{N}_{2}$ fixed by the legumes. This analysis was performed for each of the experimental years, and the block was included as a random factor. In the case of the forage crop biomass in May and August 2016 (Expt. 1), cutting time was also included as a random factor. Pairwise comparisons test in the model was performed using the Tukey method to adjust for multiple comparisons. All statistical analyses were computed in the open-source program R (R Core Team 2020) using the R packages emmeans and lmerTest (Kuznetsova et al. 2017).

\section{Results and discussion}

\subsection{Effect of undersown forage or cover crops on the first crops of the crop sequence}

At the harvest of the first crop in 2015 (Expt. 1), the different combinations of undersown forage crops (i.e., second crops, functioning as cover crops at this early time point in the sequence) were not found to have any significant effect on the total biomass and grain yields of the main faba bean or oat crops (Table 1). This is consistent with the findings reported by Hauggaard-Nielsen et al. (2009, 2012), who neither observed any effect of an undersown clover-grass cover crop on the dry matter yields of faba bean or oats in a temperate organic cropping system with sandy loam soils. Conversely, other studies have shown that the inclusion of an undersown cover crop mixture improved cereal grain yields in the main crop in organic farming systems (Doltra and Olesen 2013), while a recent review on cover crop practices found that the main crop grain yield may be reduced by an undersown cover crop in comparison with no cover crop (Abdalla et al. 2019). However, the large range of main crops included in the analysis may eliminate the effects of cover crops on individual main crops with potentially different responses to the treatment. Nonetheless, cover crops may provide several other benefits, such as inputs of biologically fixed $\mathrm{N}$, weed reduction, soil carbon sequestration, nutrient retention, and reduced risk of soil erosion, among others (Hauggaard-Nielsen et al. 2009; Hunter et al. 2019). Furthermore, $\mathrm{N}_{2}$-fixing faba bean crop accumulated a higher amount of $\mathrm{N}$ than oats in Expt. 1, as expected (Table 2), and there was a high variation depending on the forage crop treatment. Indeed, the effects of undersown cover crop on the grain $\mathrm{N}$ yield of the cash crop might vary, being positive with a legume cover crop, negative with nonlegumes, and neutral effect for legume-non-legume cover crop mixtures (Abdalla et al. 2019). The weed biomass in the first crops was not influenced by the early stages of the forage crops nor by the cover crops (Fig. 3a). But there was an interaction between the effect of the first crop and the forage crop on weed $\mathrm{N}$ accumulation (Table 2), which was higher $\mathrm{N}$ in faba bean than in oats and likely reflected a higher soil availability of $\mathrm{N}$ due to the symbiotic $\mathrm{N}_{2}$ fixation in faba bean. Furthermore, $\mathrm{N}$ accumulation in the weeds under faba bean was significantly higher in the treatment with $\mathrm{RC}+\mathrm{T}$ than in $\mathrm{RC}$.

In 2016, the biomass and grain yield of the faba bean and oats was not affected by the undersown cover crops. However, the biomass of the oats in the intercrop with faba bean showed 


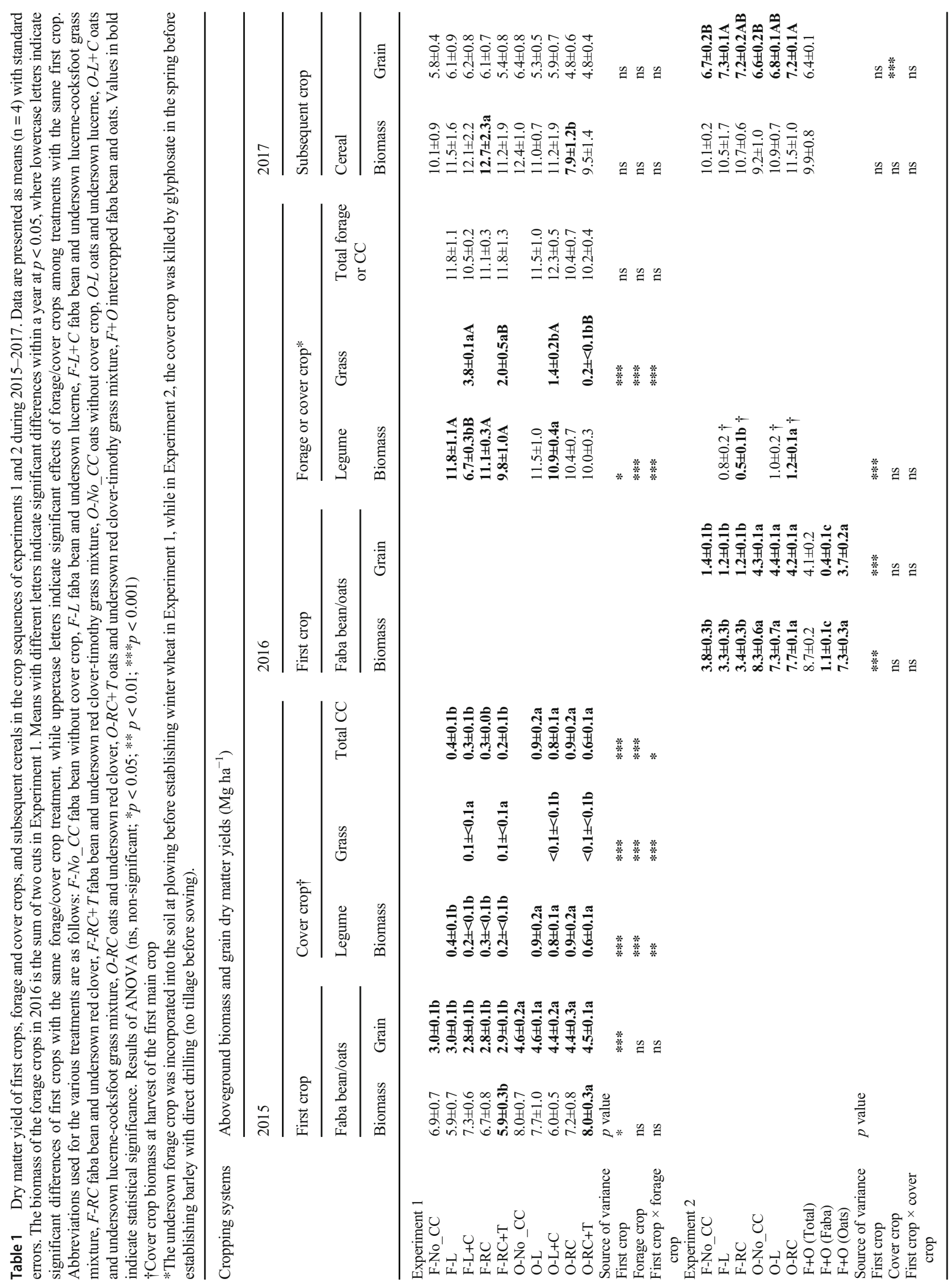


similar values as the oats with undersown cover crops, while the biomass of the faba bean component was considerably lower than the biomass of faba bean when undersown with cover crops (Expt. 2; Table 1). Cereals have been proven to suppress red clover biomass accumulation, while the cereal crop is still present (Gaudin et al. 2013). Early biomass accumulation by the oats (Fradgley et al. 2017) could have resulted in the shading of the undersown forage and cover crop, thus limiting their growth during this phase. However, the competitive pressure is lowered after the cereal harvest, thus allowing for improved growth later in the season (Bergkvist et al. 2011). Similar to Expt. 1, the undersown cover crops did not show any effect on the weed biomass in the first crop of the sequence (Fig. 3d).

In the context and conditions of this study, adding a forage or cover crop into the first crop did not show any effect on yield in the main crop, which agrees with our first hypothesis. In this early stage of the crop sequence, detectable benefits from facilitation processes cannot be expected. However, having no negative influence from the cover or forage crop on the first crop imply that the crop sequence components complement each other, possibly exploiting different spatial sources of nutrients and water and allowing for an adequate light capture.

\subsection{Forage crops}

\subsubsection{Forage crops-cover crop phase}

In the first year (2015) of the crop sequence, the total biomass production of the forage crops (which at this stage are functioning as undersown cover crops) was significantly higher for oats than faba bean in all treatments (Expt. 1; Table 1). Similar results were found for the legume component of the forage crops, while the grass component produced more biomass having faba bean as the first crop than in the oats crop. De Notaris et al. (2021) found similar results of less biomass of the undersown cover crop mixtures in faba bean than oats in long-term organic crop rotation in a temperate climate with different fertility management (with and without animal manure; between 80 and $110 \mathrm{~kg} \mathrm{~N} \mathrm{ha}^{-1}$ ), which was attributed mainly to the longer growth period of the faba bean (faba bean was harvested 2-3 weeks after the cereal). The aboveground growth pattern of oats provides less shading than does faba bean, thus resulting in better light conditions for the early stages of the forage crop. Moreover, the biological $\mathrm{N}_{2}$ fixation is increased under the coexistence with a cereal or grass crop (Peoples et al. 2001), which might have positive implications for the resulting amount of legume forage crop biomass produced when grown a preceding cereal crop compared to when undersown in a grain legume crop. This facilitation process may be explained by the benefits of species mixture with different plant functional traits. Furthermore, the undersown forage crops showed lower total $\mathrm{N}$ accumulation in faba bean than in oats, despite that the cereal crop is expected to compete more strongly for soil $\mathrm{N}$ than the $\mathrm{N}_{2}$-fixing faba bean crop (Table 2). The relative proportions of legume and grass biomass in the forage crop mixtures indicate that the forage legumes were more competitive against grass when undersown in oats treatments than in faba bean (Hauggaard-Nielsen et al. 2012). In the first year of the crop sequence, when the forage crops were functioning as undersown cover crops, the weed biomass seemed to be higher in the faba bean-preceding crop compared to in the oats, but the difference was not statistically significant (Fig. 3a). This is consistent with the findings of Hill et al. (2016), claiming the higher availability of $\mathrm{N}$ from faba bean to promote weed growth.

\subsubsection{Forage crops-cash crop phase}

In the second year of the crop sequence, the total biomass of the forage crop did not show any difference between the treatments. However, the biomass of both legume and grass was affected by the first crop and the forage crop composition. In particular, lucerne biomass was strongly reduced in the $\mathrm{L}+\mathrm{C}$ mixture compared to the other cover crop treatments after faba bean and compared to $\mathrm{L}+\mathrm{C}$ after oats as the first crop (Table 1). Furthermore, the grass biomass was higher after faba bean than after oats. The forage grass may have benefitted more when undersown in faba bean than in oats due to less intense competition for plant-available soil $\mathrm{N}$ from faba bean. In addition, the more N-rich plant residues of faba bean are likely to contribute to further increases in soil $\mathrm{N}$ availability for grasses undersown in faba bean than in oats. This is in accordance with previous findings (Hauggaard-Nielsen et al. 2012; Neugschwandtner et al. 2015), where the increase in soil $\mathrm{N}$ availability due to the grain legume improves the growth of the grass compared to the forage legume. This may be due to the ability of grasses to better compete for soil mineral N (Blanco-Canqui et al. 2015). Indeed, the grass forage crops showed a higher amount of $\mathrm{N}$ accumulated after faba bean than after oats, and higher $\mathrm{N}$ accumulation was seen in cocksfoot than in timothy after both faba bean and oats (Table 2). The only significant difference in total forage crop $\mathrm{N}$ accumulation during 2016 (sum of the two biomass harvests) was that it was higher in the lucerne and cocksfoot mixture after oats than after faba bean. This may be supported by the higher Ndfa in lucerne grown together with cocksfoot after oats than after faba bean (211 vs $94 \mathrm{~kg} \mathrm{~N} \mathrm{ha}^{-1}$ ) (Fig. 4). The results on Ndfa indicate that the forage legumes acquired a large part, often more than $50 \%$, of their $\mathrm{N}$ from soil, with lucerne in mixture with cocksfoot after oats being the main exception with a relatively high proportion of $\mathrm{N}$ from $\mathrm{N}_{2}$ fixation (Fig. 4). Forage legumes undersown in faba bean likely had access to relatively high levels of soil $\mathrm{N}$, due both to the inputs of fixed $\mathrm{N}$ from faba bean and the lack of competition 


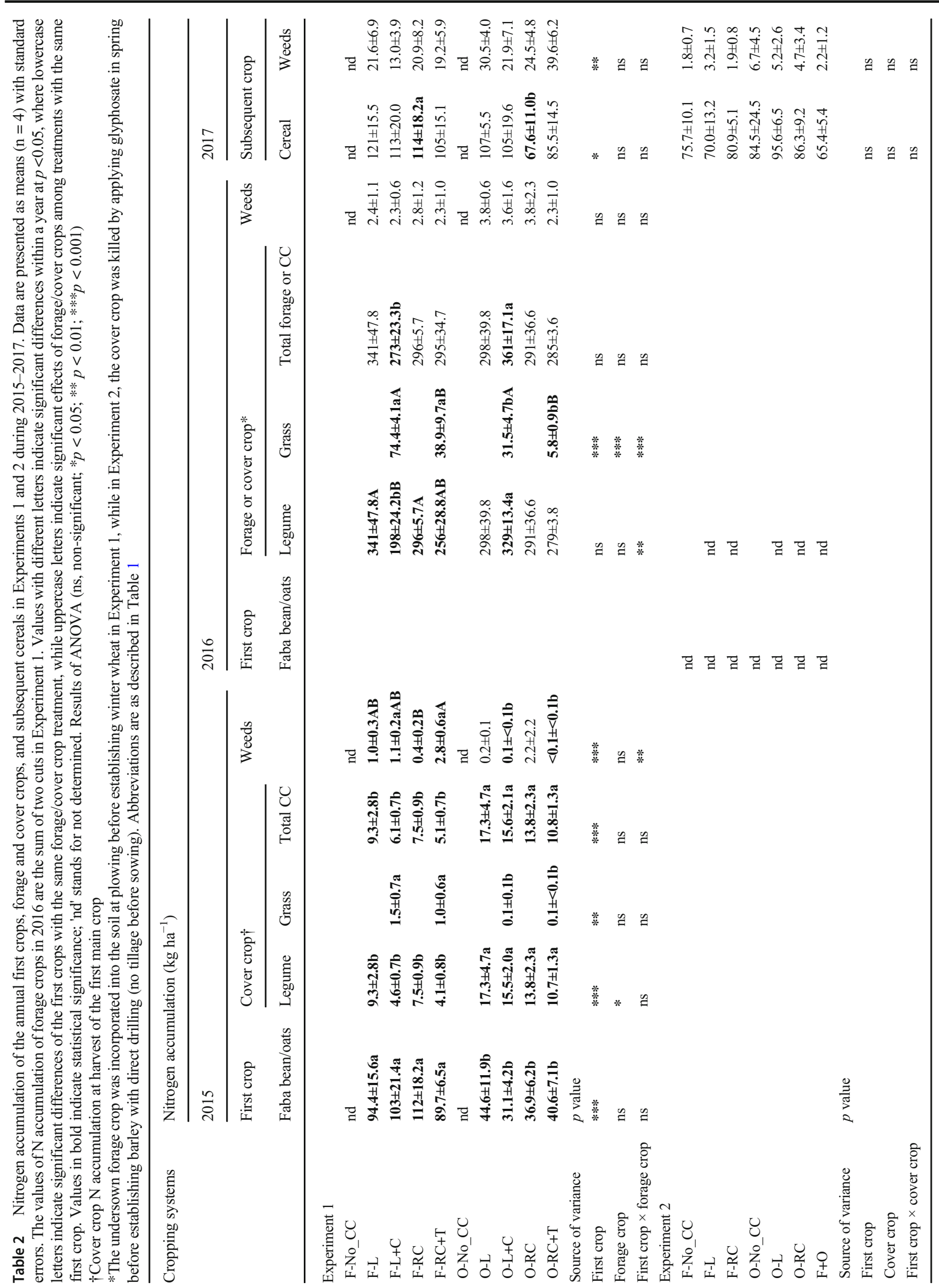


Fig. 3 The weed dry biomass (DM) during 2015-2017, in Experiment $1(\mathbf{a}, \mathbf{b}, \mathbf{c})$ and Experiment 2 (d, e). Values are means $(n=4)$ with standard errors of treatments in the crop sequence. The first crops are faba bean (green) and oats (orange), which were grown without a forage/cover crop (No_CC) and undersown with forage/cover crops: lucerne (L), lucernecocksfoot grass mixture $(\mathrm{L}+\mathrm{C})$, red clover $(\mathrm{RC})$, and red clovertimothy grass mixture $(\mathrm{RC}+\mathrm{T})$. Experiment 2 includes an additional treatment of intercropped faba bean and oats (blue). In Experiment 1, the data for forage crops in 2016 are the mean of two cuts. Bars with different letters indicate significant differences within a year at $p<0.05$, where lowercase letters indicate significant differences of the first crops with the same forage/cover crop treatment, while uppercase letters indicate significant effects of forage/cover crops among treatments with the same first crop. Note the differences in scale on the $y$-axis between subfigures. Abbreviations used for the various treatments are defined in Table 1.
EXPT. 1.

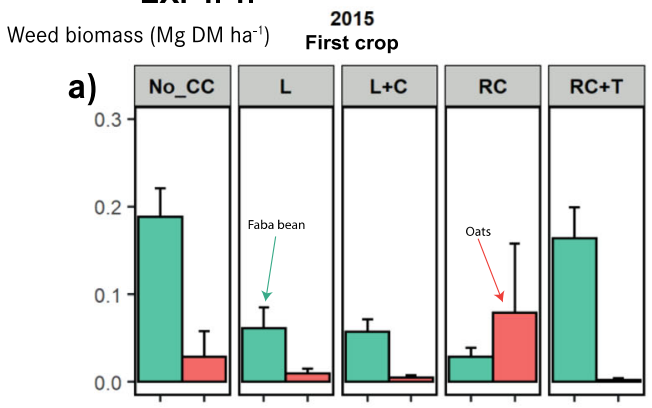

2016
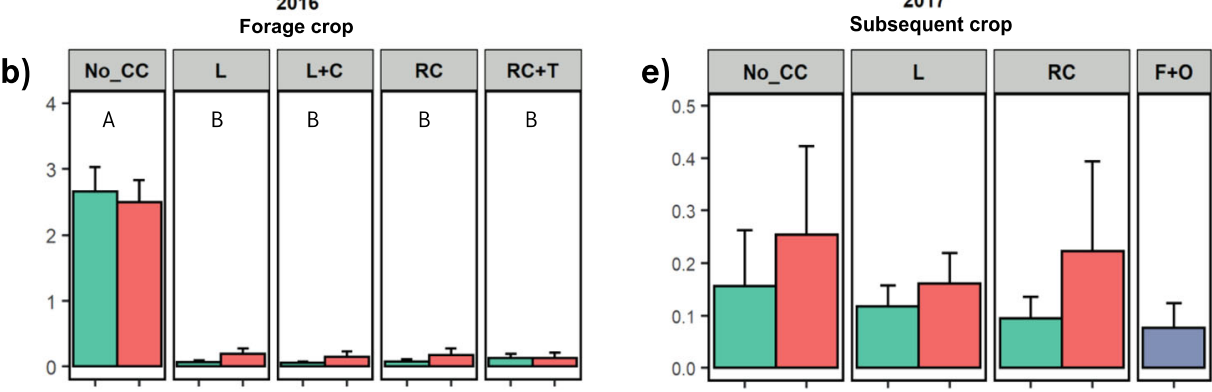

EXPT. 2.

Weed biomass (Mg DM ha-1) $\begin{array}{cc}2016 \\ \text { First crop }\end{array}$

d)

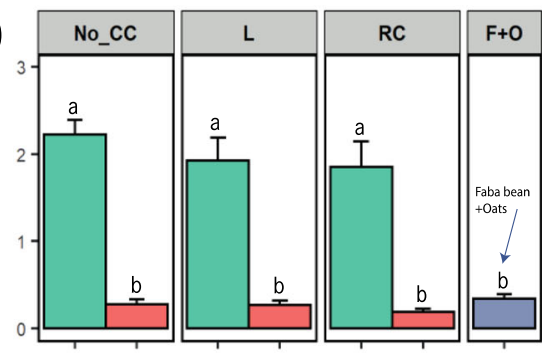

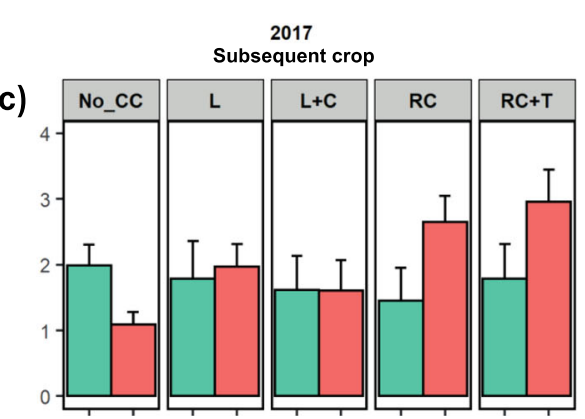

for soil $\mathrm{N}$ from cereals or grasses. When interpreting these results, it is important to be aware of the limited precision of the ${ }^{15} \mathrm{~N}$ natural abundance method. We observed that the difference in ${ }^{15} \mathrm{~N}$ between reference plants and the $\beta$ values of lucerne and red clover was sometimes less than $5 \delta^{15} \mathrm{~N}$ units, which limits the precision when calculating Ndfa (Unkovich et al. 2008; Carlsson and Huss-Danell 2014). Despite this methodological uncertainty, our results showed a clear positive effect of the presence of oats and cocksfoot on symbiotic $\mathrm{N}_{2}$ fixation in lucerne (Fig. 4), which follows the logic that the cereal and grass competed efficiently for soil $\mathrm{N}$ and forced lucerne to rely relatively more on $\mathrm{N}_{2}$ fixation.

Perennial legumes may deposit $\mathrm{N}$ that can be recovered by grasses in cover crop mixtures (Schipanski and Drinkwater 2012). Reiss and Drinkwater (2020) reported no difference in the amount or the proportion of legume $\mathrm{N}$ derived from $\mathrm{N}_{2}$ fixation in a cover crop mixture compared to the same legumes as sole cover crop. Frankow-Lindberg et al. (2009) showed that mixtures of forage crops have a higher ability to suppress weeds but also pointed out red clover as a weaker competitor. However, our results did not show any difference among the forage legumes and legume grass mixtures in their weed suppression during the second year of the forage crops (Fig. 3b). In addition, there was no difference in the weeds $\mathrm{N}$ accumulation either between crops or between preceding crops in the second year (Table 2). We argue that wellestablished and dense forage stands developed all treatments with undersown forage crops, thus restricting the weeds through limited access to light and/or belowground growth resources (Ringselle et al. 2017). The treatments without undersown forage crops correspond to including a 1-year fallow in the crop sequence, which is a very uncommon practice in arable cropping systems with similar conditions as the present study but used in some semiarid temperate areas. It can therefore be argued that the comparisons between the presence and absence of a forage crop during the second year have little agronomic interest. Nevertheless, it was necessary to include the treatments without forage crops to assess if and how the 


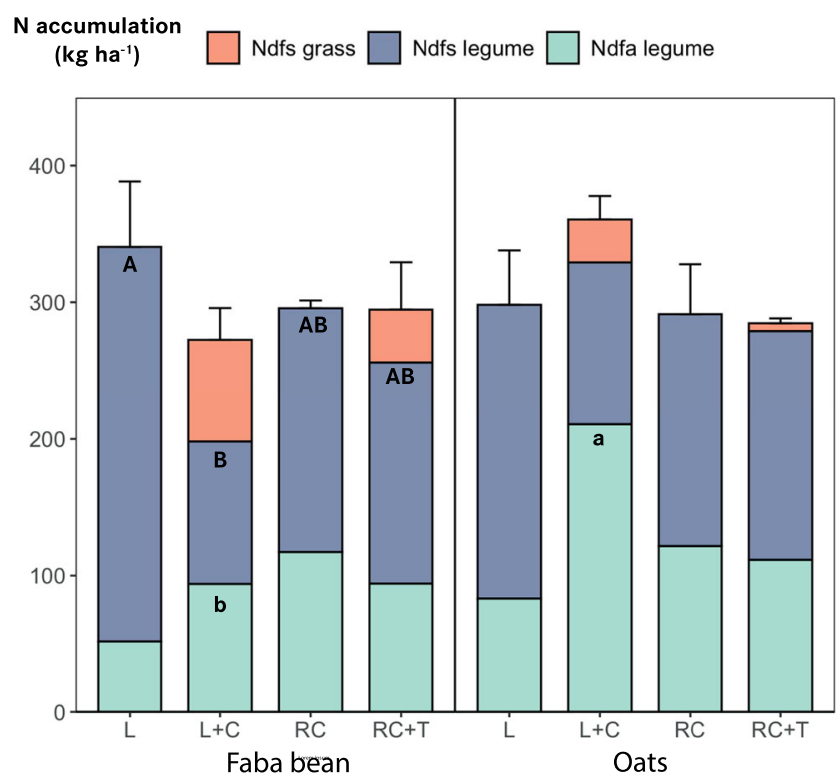

Fig. 4 The $\mathrm{N}$ accumulated from the soil (Ndfs) by grass and legume forage crops and the $\mathrm{N}$ accumulated through biological fixation of $\mathrm{N}_{2}$ from the atmosphere (Ndfa) by legume forage crops as affected by the first crops in Experiment 1 during 2016. Bars with different letters indicate significant differences for the legume $\mathrm{N}$ sources ( $\mathrm{Ndfa}$ and Ndfs legume) at $p<0.05$, where lowercase letters indicate significant differences of the first crops with the same forage crop treatment, while uppercase letters indicate significant effects of forage crops among treatments with the same first crop. Abbreviations used for the various treatments are defined in Table 1.

undersown forage crops affect the first crop in the sequence.

\subsection{Cover crops}

The total biomass production of the cover crops in Expt. 2 was significantly higher only for red clover undersown in oats than in faba bean (Table 1). Furthermore, the cover crops biomass was slightly higher than the biomass obtained in the forage sole legumes in 2015 (Expt. 1). Several studies have shown higher aboveground biomass produced by undersown cover crops (e.g., red clover) at winter wheat harvest in stockless organic farming systems (Amossé et al. 2014) and conventional based cereal systems in similar climate conditions to our field experiment (Bergkvist et al. 2011). Furthermore, results showed no significant effect between the legume cover crops. Contrary to our results, Amossé et al. (2014) found greater biomass accumulation by the red clover than the lucerne cover crop due to a higher $\mathrm{N}$ accumulation by the red clover, thus indicating better competition by the red clover than lucerne against the winter wheat.

Previous research has shown contrasting effects of cover crops on weed suppression, from less successful (Teasdale 1996; Hiltbrunner et al. 2007) to greater weed suppression with increasing cover crop biomass (Finney et al. 2016; Hill et al. 2016). In the present study, no weed suppression by the cover crops was confirmed (Fig. 3d), which further highlights the context specificity of cover crop-weed interactions. However, the biomass of weeds was lower in oats and the faba bean-oats intercrop compared to the faba bean sole crop (Fig. 3d). The improved weed suppression when adding a cereal as an intercrop with a grain legume is one of the key benefits reported in previous intercropping research (Bedoussac et al. 2015).

\subsection{Subsequent crops}

The subsequent winter wheat crop biomass or grain yield (Expt. 1; 2017) did not show any consistent response to the first crops or forage crops (Table 1). However, the total biomass production of winter wheat after faba bean undersown with red clover was higher than when oats were undersown with red clover. Hauggaard-Nielsen et al. $(2009,2012)$ found similar results in that subsequent spring wheat production did not vary with different preceding crops. However, they observed a significant reduction in the wheat yield when a clover-grass cover crop was undersown in the previous crop. This response was accompanied by a lower availability of $\mathrm{N}$ in the soil (Hauggaard-Nielsen et al. 2009), suggesting an enhanced competition for soil $\mathrm{N}$ by the cover crop, short-term $\mathrm{N}$ immobilization when incorporating cover crop biomass, and, consequently, a reduced $\mathrm{N}$ availability for the subsequent wheat crop compared to the treatment without undersown grass clover. In the present study, the subsequent spring barley (Expt. 2) was not influenced by the first crop (faba bean or oats) as observed by Hauggaard-Nielsen et al. (2009, 2012). This might be because of the relatively poor growth of faba bean in 2016, limiting the amount of $\mathrm{N}$ inputs in faba bean residues, and/or that the faba bean residue was slowly mineralized. The grain yield was higher when lucerne was included as an undersown cover crop in faba bean and when red clover was included in oats than in the treatments without a cover crop (Table 1). In particular, the results underline that legume cover crops can provide benefits in terms of increased crop yields in cereal-based cropping systems and also that a legume cover crop can partly compensate for low $\mathrm{N}$ inputs from the first crop (main crop). Doltra and Olesen (2013) demonstrated that spring barley was less responsive to the effect of previous cover crops due to lower $\mathrm{N}$ recovery efficiency. However, the magnitude of this effect depended strongly on the cereal species, cover crop species, and on soil and crop rotation type. The treatments without a forage crop in Expt. 1 (No_CC) were included mainly to assess the competition resulting from undersowing forage crops on first crop performance. We found that the winter wheat yield was as high after no forage crop as after undersown of forage legumes. However, as discussed above (end of Section 3.2), the practical relevance of the fallow (No_CC) may be questioned, since for many farmers, it would mean a reduction in income. 
The subsequent winter wheat crop consistently accumulated larger amounts of $\mathrm{N}$ after faba bean than after oats, although the difference was only significant in the treatment with red clover as a forage crop. Usually, the $\mathrm{N}$ availability for the subsequent crops depends on the $\mathrm{N}$ accumulation provided by the preceding legume crops, which is most often linked to their production of biomass (Bergkvist et al. 2011). However, there may be other factors affecting the $\mathrm{N}$ availability such as $\mathrm{C} / \mathrm{N}$ and $\mathrm{N} /$ lignin ratio as well as the placement of the cover crop, i.e., whether incorporated into the soil or left on the soil surface. The lack of significant differences in winter wheat yield and $\mathrm{N}$ accumulation after forage crops may be explained by the fact that all the aboveground forage biomass had been removed, and thus a large part of the fixed $\mathrm{N}$ has left the cropping system. However, residues from roots and stubbles are expected to leave a legacy of $\mathrm{N}$ in the rotation, where the $\mathrm{C} / \mathrm{N}$ ratio of forage crop residues influences the synchrony between $\mathrm{N}$ mineralization and $\mathrm{N}$ demand of the following crop (Blesh et al. 2019). According to Høgh-Jensen et al. (2004), roots and stubble contain the equivalent of $25 \%$ of the total amount of fixed $\mathrm{N}$ in harvested aboveground biomass of lucerne and red clover, which in our case corresponds to $10-50 \mathrm{~kg}$ fixed $\mathrm{N}$ per ha left in the field after the second harvest of the forage crops in Expt. 1. Asynchrony, through the potential short-term immobilization of $\mathrm{N}$, may have limited the use of the residual $\mathrm{N}$ by the subsequent winter wheat in the present study, and some of this $\mathrm{N}$ might become available for crops later in the rotation. In Expt. 2, the combination of diversified crop rotations with legumes, cover crops, and intercrops showed no significant differences for the $\mathrm{N}$ accumulation in the spring barley. Long-term experiments have shown yield improvements in crop rotations, including grass-legume leys (Persson et al. 2008), and the crop diversification of our experiments might, thus, be expected to benefit cereal grain yields in a longer perspective (Bowles et al. 2020).

In the present study, the inclusion of a forage crop did not result in any effect on weed biomass in the subsequent winter wheat (Fig. 3c). Several studies highlighted the benefits of implementing green manures (perennial legumes as a sole crop or in plant mixtures) in the crop rotation for weed suppression, by limiting the input of new seeds in the weed seed bank (Melander et al. 2020) or by leaving the green manure for longer periods (Sjursen et al. 2012). Indeed, weed biomass is a less suitable indicator for understanding the mechanism of plant-plant competition than plant density or ground cover by weeds. From the present study, we cannot discern whether forage crops also have had a weed-suppressing effect in the subsequent winter wheat, and that this effect was counteracted by cover crop plants re-emerging as weeds in the subsequent crop. Conversely, in organic crop rotation, green manures (plant material was removed) presented a residual effect on weed seed banks 3 years after termination (Melander et al.
2020). These results may be influenced by the duration of the green manure, lack of soil disturbance, and the ability of the green manure to re-grow. Furthermore, in Expt. 1, red clover was encountered among the weed samples collected from the subsequent winter wheat, indicating a poor effect of the tillage and herbicide (or a strong effect of the clover to survive). There is evidence that cover crops may return as volunteer weeds in the subsequent crop, thus limiting the effect of the cover crop on weed suppression and the yield of the subsequent crop (MacLaren et al. 2019). Likewise, cover crops in Expt. 2 did not show any effect on weed suppression in the following crop (Fig. 3e). Several factors such as cover crop growth and biomass, decomposition rate, and method of termination (Blanco-Canqui et al. 2015) or increase in $\mathrm{N}$ supply by legume cover crops (Sjursen et al. 2012) may have influenced the weed biomass in the spring barley. Salonen and Ketoja (2020) demonstrated a limited effect of cover crops on weed suppression in organic cereal-based rotations under reduced tillage. Furthermore, no significant differences were observed in the $\mathrm{N}$ accumulation in weeds in the subsequent cereal crops in either of the two experiments (Table 2). The total $\mathrm{N}$ accumulated by the weeds was higher after oats in both experiments, although this was not statistically significant.

The present study hypothesized that the yield and total $\mathrm{N}$ accumulation of the subsequent cereal would be influenced by preceding crops in the sequence. This was not fully achieved by the different combinations of crop diversification practices. However, adding a cover crop in the rotation increased the grain yield of the spring barley, and adding a forage crop in combination with faba bean in the crop rotation tended to increase the yield of the winter wheat for both the biomass $(p=0.2)$ and grain $(p=0.5)$. Furthermore, we hypothesized that forage and cover crops could increase weed suppression. However, this effect might be dependent on other management factors and plant species interactions. It is also possible that the relatively small plot size used in our experiments $(2 \times$ $12 \mathrm{~m}$ ) was not sufficient for capturing potential patchiness in the weed distribution, which might have caused large variations and thus reduced the possibility to obtain statistically significant differences in weed biomass. Since the results of this study did not show any penalty on the subsequent crop by the weed biomass, there may be other services provided by either the crops in the rotation or weed diversity. There are still challenges associated with the implementation of crop diversification practices, such as better synchrony of the crops in the rotation.

The novelty of this study lies in the combination of different crop diversification practices in cereal-based crop sequences in a temperate climate. We intended to give insights on how diversified crop rotations relate to resource acquisition by understating plant species interactions. The results demonstrated that replacing cereal with a grain legume earlier in the 
sequence and the addition of forage or cover crops had either neutral or positive effects and could partly compensate for the low preceding crop effects from cereals in less diverse cerealbased cropping systems in terms of crop productivity and $\mathrm{N}$ acquisition. Our findings thus show promising effects of combining several crop diversification practices in crop rotations and highlight the need for continued research for identifying and optimizing the positive long-term effects of combined crop diversification practices.

\section{Conclusions}

Crop diversification practices through diversified rotation, cover crops, and intercropping did not show a strong influence on the performance of components of the crop sequence in terms of productivity, weed suppression, and nitrogen acquisition. Until now, studies on the combination of crop diversification practices have been rare, and our results demonstrate the complexity among different plant-plant interactions in diversified crop sequences. Although diversified rotation and forage or cover crops may not directly benefit all agroecosystem functions measured in this study, the benefits of crop diversification should be considered in a wider perspective since implementing the crop diversification practices studied here did not cause yield penalties or other trade-offs with the agronomic performance of the crops. This is a valuable finding for the feasibility of crop diversification to promote other ecosystem services, not studied here, such as enhanced associated biodiversity, increased soil carbon inputs, reduced risks of soil erosion and nutrient losses, and reduced dependency on inputs. To further improve the knowledge about ecosystem functions in diversified cropping systems, more research is needed about combined diversification practices, including longer crop sequences and/or a more longterm crop rotation perspective and covering different edapho-climatic conditions. Further research is also needed to elucidate the mechanistic plant-soil interactions in diversified crops and cropping systems, including effects of soil nitrogen availability and feedbacks on short- and long-term soil nitrogen dynamics.

Acknowledgements The field experiments in this study were made possible by the Swedish Infrastructure for Ecosystem Science (SITES), in this case, at Lönnstorp Research Station at SLU, Alnarp. We also thank the anonymous reviewers whose suggestions helped to improve the paper.

Code availability Not applicable.

Authors' contributions Conceptualization: C.R., G.C., and E.S.J. Investigation: C.R. and G.C. Formal analysis: C.R. Visualization: C.R. Writing-original draft: C.R. and L.M.D.M. Writing-review and editing: C.R., E.S.J, L.M.D.M., and G.C. Funding Acquisition: E.S.J.
Funding Open access funding provided by the Swedish University of Agricultural Sciences. The LEGATO project (Legumes for the Agriculture of Tomorrow) was funded by the European Union FP7 under grant agreement No. 613551.

Data availability The datasets generated and analyzed during the present study are available from the corresponding author on reasonable request.

\section{Declarations}

Conflict of interest The authors declare no competing interests.

Ethics approval Not applicable.

Consent to participate Not applicable.

Consent for publication Not applicable.

Open Access This article is licensed under a Creative Commons Attribution 4.0 International License, which permits use, sharing, adaptation, distribution and reproduction in any medium or format, as long as you give appropriate credit to the original author(s) and the source, provide a link to the Creative Commons licence, and indicate if changes were made. The images or other third party material in this article are included in the article's Creative Commons licence, unless indicated otherwise in a credit line to the material. If material is not included in the article's Creative Commons licence and your intended use is not permitted by statutory regulation or exceeds the permitted use, you will need to obtain permission directly from the copyright holder. To view a copy of this licence, visit http://creativecommons.org/licenses/by/4.0/.

\section{References}

Abdalla M, Hastings A, Cheng K, Yue Q, Chadwick D, Espenberg M, Truu J, Rees RM, Smith P (2019) A critical review of the impacts of cover crops on nitrogen leaching, net greenhouse gas balance and crop productivity. Glob Chang Biol 25(8):2530-2543. https://doi. org/10.1111/gcb.14644

Altieri MA, Nicholls CI, Henao A, Lana MA (2015) Agroecology and the design of climate change-resilient farming systems. Agron Sustain Dev 35(3):869-890. https://doi.org/10.1007/s13593-015-0285-2

Amossé C, Jeuffroy M-H, Mary B, David C (2014) Contribution of relay intercropping with legume cover crops on nitrogen dynamics in organic grain systems. Nutr Cycl Agroecosyst 98(1):1-14. https:// doi.org/10.1007/s10705-013-9591-8

Angus JF, Kirkegaard JA, Hunt JR, Ryan MH, Ohlander L, Peoples MB (2015) Break crops and rotations for wheat. Crop Pasture Sci 66(6): 523-552. https://doi.org/10.1071/cp14252

Bedoussac L, Justes E (2010) Dynamic analysis of competition and complementarity for light and $\mathrm{N}$ use to understand the yield and the protein content of a durum wheat-winter pea intercrop. Plant Soil 330(1-2):37-54. https://doi.org/10.1007/s11104-010-0303-8

Bedoussac L, Journet E-P, Hauggaard-Nielsen H, Naudin C, CorreHellou G, Jensen ES, Prieur L, Justes E (2015) Ecological principles underlying the increase of productivity achieved by cereal-grain legume intercrops in organic farming. A review Agron Sustain Dev 35(3):911-935. https://doi.org/10.1007/s13593-014-0277-7

Bergkvist G, Stenberg M, Wetterlind J, Båth B, Elfstrand S (2011) Clover cover crops under-sown in winter wheat increase yield of subsequent spring barley — effect of $\mathrm{N}$ dose and companion grass. Field 
Crop Res 120(2):292-298. https://doi.org/10.1016/j.fcr.2010.11. 001

Blanco-Canqui H, Shaver TM, Lindquist JL, Shapiro CA, Elmore RW, Francis CA, Hergert GW (2015) Cover crops and ecosystem services: insights from studies in temperate soils. Agron J 107(6): 2449-2474. https://doi.org/10.2134/agronj15.0086

Blesh J, VanDusen BM, Brainard DC (2019) Managing ecosystem services with cover crop mixtures on organic farms. Agron J 111(2): 826-840. https://doi.org/10.2134/agronj2018.06.0365

Bowles TM, Mooshammer M, Socolar Y, Calderón F, Cavigelli MA, Culman SW, Deen W, Drury CF, Garcia y Garcia A, ACM G, Harkcom WS, Lehman RM, Osborne SL, Robertson GP, Salerno J, Schmer MR, Strock J, Grandy AS (2020) Long-term evidence shows that crop-rotation diversification increases agricultural resilience to adverse growing conditions in North America. One Earth 2(3):284-293. https://doi.org/10.1016/j.oneear.2020.02.007

Brandt M, Grahn G (1998) Avdunstning och avrinningskoefficient i Sverige 1961-1990 Beräkningar med HBV-modellen [Evaporation and runoff coefficient in Sweden 1961-1990 Calculations with the HBV model]. Hydrology SMHI

Carlsson G, Huss-Danell K (2014) Does nitrogen transfer between plants confound $15 \mathrm{~N}$-based quantifications of N2 fixation? Plant Soil 374(1):345-358. https://doi.org/10.1007/s11104-013-1802-1

Core Team R (2020) R: A language and environment for statistical computing. R Foundation for Statistical Computing, Vienna, Austria https://www.R-project.org/

Davis AS, Hill JD, Chase CA, Johanns AM, Liebman M (2012) Increasing cropping system diversity balances productivity, profitability and environmental health. PLoS One 7(10):e47149. https:// doi.org/10.1371/journal.pone.0047149

De Notaris C, Mortensen EØ, Sørensen P, Olesen JE, Rasmussen J (2021) Cover crop mixtures including legumes can self-regulate to optimize N2 fixation while reducing nitrate leaching. Agric Ecosyst Environ 309:107287. https://doi.org/10.1016/j.agee.2020.107287

Doltra J, Olesen JE (2013) The role of catch crops in the ecological intensification of spring cereals in organic farming under Nordic climate. Eur J Agron 44:98-108. https://doi.org/10.1016/j.eja. 2012.03.006

Finney DM, White CM, Kaye JP (2016) Biomass production and carbon/ nitrogen ratio influence ecosystem services from cover crop mixtures. Agron J 108(1):39-52. https://doi.org/10.2134/agronj15.0182

Fradgley NS, Creissen HE, Pearce H, Howlett SA, Pearce BD, Döring TF, Girling RD (2017) Weed suppression and tolerance in winter oats. Weed Technol 31(5):740-751. https://doi.org/10.1017/wet. 2017.46

Frankow-Lindberg BE, Brophy C, Collins RP, Connolly J (2009) Biodiversity effects on yield and unsown species invasion in a temperate forage ecosystem. Ann Bot 103(6):913-921. https://doi.org/ 10.1093/aob/mcp008

Gaudin ACM, Westra S, Loucks CES, Janovicek K, Martin RC, Deen W (2013) Improving resilience of northern field crop systems using inter-seeded red clover: a review. Agronomy 3(1):148-180

Hauggaard-Nielsen H, Mundus S, Jensen ES (2009) Nitrogen dynamics following grain legumes and subsequent catch crops and the effects on succeeding cereal crops. Nutr Cycl Agroecosyst 84(3):281-291. https://doi.org/10.1007/s10705-008-9242-7

Hauggaard-Nielsen H, Mundus S, Jensen ES (2012) Grass-clover undersowing affects nitrogen dynamics in a grain legume-cereal arable cropping system. Field Crop Res 136:23-31. https://doi.org/ 10.1016/j.fcr.2012.07.001

Hill EC, Renner KA, Sprague CL, Davis AS (2016) Cover crop impact on weed dynamics in an organic dry bean system. Weed Sci 64(2):261275. https://doi.org/10.2307/26420689

Hiltbrunner J, Liedgens M, Bloch L, Stamp P, Streit B (2007) Legume cover crops as living mulches for winter wheat: components of biomass and the control of weeds. Eur J Agron 26(1):21-29. https://doi.org/10.1016/j.eja.2006.08.002

Høgh-Jensen H, Loges R, Jørgensen FV, Vinther FP, Jensen ES (2004) An empirical model for quantification of symbiotic nitrogen fixation in grass-clover mixtures. Agric Syst 82(2):181-194. https://doi.org/ 10.1016/j.agsy.2003.12.003

Hunter MC, Schipanski ME, Burgess MH, LaChance JC, Bradley BA, Barbercheck ME, Kaye JP, Mortensen DA (2019) Cover crop mixture effects on maize, soybean, and wheat yield in rotation. Agric Environ Lett 4(1):180051. https://doi.org/10.2134/ael2018.10.0051

Kuznetsova A, Brockhoff PB, Christensen RHB (2017) 1merTest Package: tests in linear mixed effects models. J Stat Softw 82(13): 26. https://doi.org/10.18637/jss.v082.i13

Landis DA (2017) Designing agricultural landscapes for biodiversitybased ecosystem services. Basic Appl Ecol 18:1-12. https://doi. org/10.1016/j.baae.2016.07.005

LantMet-SLU (2020) The climatic station network of the Swedish University of Agricultural Sciences. http:/www.ffe.slu.se/lm/ LMHome.cfm?LMSUB=0\&ADM=0. Accessed 2020-09-01

Liebman M, Dyck E (1993) Crop rotation and intercropping strategies for weed management. Ecol Appl 3(1):92-122. https://doi.org/10.2307/ 1941795

MacLaren C, Swanepoel P, Bennett J, Wright J, Dehnen-Schmutz K (2019) Cover crop biomass production is more important than diversity for weed suppression. Crop Sci 59(2):733-748. https://doi. org/10.2135/cropsci2018.05.0329

Melander B, Rasmussen IA, Olesen JE (2020) Legacy effects of leguminous green manure crops on the weed seed bank in organic crop rotations. Agric Ecosyst Environ 302:107078. https://doi.org/10. 1016/j.agee.2020.107078

Neugschwandtner R, Ziegler K, Kriegner S, Wagentristl H, Kaul H-P (2015) Nitrogen yield and nitrogen fixation of winter faba beans. Acta Agric Scand Sect B Soil Plant Sci 65(7):658-666. https://doi. org/10.1080/09064710.2015.1042028

Peoples MB, Bowman AM, Gault RR, Herridge DF, McCallum MH, McCormick KM, Norton RM, Rochester IJ, Scammell GJ, Schwenke GD (2001) Factors regulating the contributions of fixed nitrogen by pasture and crop legumes to different farming systems of eastern Australia. Plant Soil 228(1):29-41. https://doi.org/10. 1023/a:1004799703040

Peoples MB, Brockwell J, Herridge DF, Rochester IJ, Alves BJR, Urquiaga S, Boddey RM, Dakora FD, Bhattarai S, Maskey SL, Sampet C, Rerkasem B, Khan DF, Hauggaard-Nielsen H, Jensen ES (2009) The contributions of nitrogen-fixing crop legumes to the productivity of agricultural systems. Symbiosis 48(1-3):1-17. https://doi.org/10.1007/bf03179980

Persson T, Bergkvist G, Kätterer T (2008) Long-term effects of crop rotations with and without perennial leys on soil carbon stocks and grain yields of winter wheat. Nutr Cycl Agroecosyst 81(2):193-202. https://doi.org/10.1007/s10705-007-9144-0

Plaza-Bonilla D, Nolot J-M, Raffaillac D, Justes E (2017) Innovative cropping systems to reduce $\mathrm{N}$ inputs and maintain wheat yields by inserting grain legumes and cover crops in southwestern France. Eur J Agron 82:331-341. https://doi.org/10.1016/j.eja.2016.05.010

Poeplau C, Don A (2015) Carbon sequestration in agricultural soils via cultivation of cover crops - a meta-analysis. Agric Ecosyst Environ 200:33-41. https://doi.org/10.1016/j.agee.2014.10.024

Raseduzzaman M, Jensen ES (2017) Does intercropping enhance yield stability in arable crop production? A meta-analysis. Eur J Agron 91: 25-33. https://doi.org/10.1016/j.eja.2017.09.009

Reiss ER, Drinkwater LE (2020) Ecosystem service delivery by cover crop mixtures and monocultures is context dependent. Agron $\mathrm{J}$ 112(5):4249-4263. https://doi.org/10.1002/agj2.20287

Ringselle B, Prieto-Ruiz I, Andersson L, Aronsson H, Bergkvist G (2017) Elymus repens biomass allocation and acquisition as affected by 
light and nutrient supply and companion crop competition. Ann Bot 119(3):477-485. https://doi.org/10.1093/aob/mcw228

Salonen J, Ketoja E (2020) Undersown cover crops have limited weed suppression potential when reducing tillage intensity in organically grown cereals. Org Agric 10(1):107-121. https://doi.org/10.1007/ s13165-019-00262-6

Schipanski ME, Drinkwater LE (2012) Nitrogen fixation in annual and perennial legume-grass mixtures across a fertility gradient. Plant Soil 357(1-2):147-159. https://doi.org/10.1007/s11104-012-1137-3

Sjursen H, Brandsæter LO, Netland J (2012) Effects of repeated clover undersowing, green manure ley and weed harrowing on weeds and yields in organic cereals. Acta Agric Scand Sect B Soil Plant Sci 62(2):138-150. https://doi.org/10.1080/09064710.2011.584550

Teasdale JR (1996) Contribution of cover crops to weed management in sustainable agricultural systems. J Prod Agric 9(4):475-479. https:// doi.org/10.2134/jpa1996.0475

Tonitto C, David MB, Drinkwater LE (2006) Replacing bare fallows with cover crops in fertilizer-intensive cropping systems: a meta-analysis of crop yield and N dynamics. Agric Ecosyst Environ 112(1):58-72. https://doi.org/10.1016/j.agee.2005.07.003

Unkovich M, Herridge D, Peoples M, Cadisch G, Boddey B, Giller K, Alves B, Chalk P (2008) Measuring plant-associated nitrogen fixation in agricultural systems. Australian Centre for International Agricultural Research (ACIAR), Canberra

Valkama E, Lemola R, Känkänen H, Turtola E (2015) Meta-analysis of the effects of undersown catch crops on nitrogen leaching loss and grain yields in the Nordic countries. Agric Ecosyst Environ 203:93101. https://doi.org/10.1016/j.agee.2015.01.023

Wezel A, Casagrande M, Celette F, Vian J-F, Ferrer A, Peigné J (2014) Agroecological practices for sustainable agriculture. A review Agron Sustain Dev 34(1):1-20. https://doi.org/10.1007/s13593013-0180-7

Publisher's note Springer Nature remains neutral with regard to jurisdictional claims in published maps and institutional affiliations. 